\title{
PENINGKATAN KINERJA ULTRAFILTRASI ALIRAN DEAD-END PADA PENYISIHAN BAHAN ORGANIK DALAM EFLUEN IPAL DOMESTIK DENGAN PRA-PERLAKUAN KOAGULASI MENGGUNAKAN KOAGULAN TANAH LEMPUNG GAMBUT \\ PERFORMANCE IMPROVEMENT OF DEAD-END ULTRAFILTRATION IN EFFLUENT \\ DOMESTIC WASTE ORGANIC MATERIAL USING PRE-TREATMENT \\ COAGULATION WITH PEATLAND CLAY
}

\author{
Dina Puspita Sari, Mahmud, Chairul Abdi \\ Program Studi Teknik Lingkungan, Fakultas Teknik, Universitas Lambung Mangkurat Jl A. Yani Km. \\ 36,5 Banjarbaru Kalimantan Selatan, 70714, Indonesia \\ E-mail: dinapusii@gmail.com
}

\begin{abstract}
ABSTRAK
Penyisihan bahan organik dalam efluen menggunakan membran ultrafiltrasi masih memiliki kendala yaitu terbentuknya fouling pada membran. Oleh karena itu, perlu dilakukan pra-perlakuan koagulasi untuk meningkatkan kinerja membran ultrafiltrasi. Koagulan yang digunakan adalah Tanah Lempung Gambut (TLG). Tujuan utama penelitian adalah menganalisis pengaruh koagulasi terhadap kinerja membran ultrafiltrasi selulosa asetat (UF-SA) dan mendapatkan permodelan fouling membran proses hibrid koagulasi dan UF-SA. Pada penelitian ini digunakan sistem aliran dead-end dengan variasi tekanan 1 - 3 bar. Hasil penelitian menujukkan tekanan terbaik 3 bar menggunakan dosis optimum 4 mg/L mampu menyisihkan $\mathrm{UV}_{254}$ sebesar 83,9 \% serta menghasilkan fluks sebesar 162,64 L/jam.m². Permodelan yang paling tepat menggambarkan proses hibrid koagulasi dan membran UF-SA adalah Kurva Saturasi dengan R square tekanan 3 bar yaitu 1.
\end{abstract}

Kata kunci: Bahan Organik, Efluen IPAL Domestik, Koagulasi, Tanah Lempung Gambut, Ultrafiltrasi.

\begin{abstract}
Removal for organic matter in effluent using ultrafiltration membrane still has problem, causes of fouling on the membrane. Therefore, coagulation pre-treatment to improve the performance of the ultrafiltration membrane. The coagulant used is Peatland Clay (TLG). The purpose of this study was to analyze effect of coagulation ultrafiltration cellulose acetate membrane performance (UF-SA) and obtain modeling of coagulation hybrid fouling membrane processes and UF-SA. This research were conducted by dead-end filtration and operated in pressure 1-3 bar. Experimental result suggested that pressure at an 3 bar using optimum dosage of $4 \mathrm{mg} / \mathrm{L}$, removed approximately 83,9\% $U V_{254}$ and the flux obtained at an operating pressure 3 bar until 162,64 L/h.m ${ }^{2}$. Kurva Saturated was the best models to representing hybrid coagulation and membrane UF-SA (R Square $=1)$.
\end{abstract}

Keywords: Organic Matter, Effluent, Coagulation, Peatland Clay, Ultrafiltration. 


\section{PENDAHULUAN}

Perusahaan Daerah Pengelola Air Limbah (PD PAL) Kota Banjarmasin merupakan perusahaan daerah milik Pemerintah Kota yang mendapat tugas sebagai pengelola air limbah permukiman atau air limbah domestik. Berdasarkan studi pendahuluan laboratorium yang dilakukan effluen IPAL domestik masih terdapat kandungan bahan organik dalam parameter $\mathrm{UV}_{254}$ dengan rata-rata sebesar $0,1671 / \mathrm{cm}$ yang dapat mengakibatkan pencemaran sungai karena hasil air olahan tersebut langsung di alirkan ke badan sungai sehingga akan terdapat kandungan bahan organik yang berpotensi menghasilkan DBP's (Disinfection by products) karena penggunaan bahan klorin untuk proses desinfeksi. DBP's dan komponen halogenetik lainnya yang bersifat karsinogenik atau dapat menyebabkan kanker (Fitria dan Handayani, 2010).

Penyisihan kandungan bahan organik dapat di lakukan dengan proses pra-perlakuan koagulasi karena biaya lebih murah dan mudah digunakan (Dong dkk., 2007). Koagulan yang digunakan yaitu berasal dari koagulan tanah lempung gambut. Menurut Rusydi dkk (2016) lempung merupakan bahan alami yang harus dilakukan pada proses pengolahan. Pengolahan koagulasi hanya mampu menyisihkan komponan bahan organik berupa fraksi hidrofobik dengan efisiensi penyisihannya 60-70\% (Dong dkk., 2007; Rahman, 2014; Pratiwi, 2017). Penggunaan membran Ultrafiltrasi (UF) banyak dikembangkan dalam pengolahan air (Aryanti dkk., 2013). Selulosa asetat (SA) merupakan salah satu polimer yang bersifat hidrofilik, mempunyai laju penyerapan yang tinggi, ketahanan listrik yang baik dan daya tahan panas (Aprilia dan Amin, 2011). Pada sistem dead-end air umpan akan lewat/ menembus membran, dan zat terlarut dengan ukuran lebih besar dibandingkan dengan ukuran pori membran akan tertahan (Sillanpää, 2015). Tetapi yang menjadi masalah dalam teknologi membran UF ini adalah terjadinya fouling yang menjadi pembatas bagi volume air terolah yang dihasilkan serta keterbatasan umur membran (Aryanti dkk., 2013).

Berdasarkan penelitian Khulaifi (2016), nilai penyisihan $\mathrm{UV}_{254}$ dari beberapa variasi dosis tanah lempung gambut yaitu $0,5 \mathrm{~g} / \mathrm{L}$ sampai $6 \mathrm{~g} / \mathrm{L}$ mampu menurunkan zat organik sebesar $41,2 \%-80 \%$. Pada penelitian Rahman (2014), hasil uji dengan penambahan koagulan dapat memberikan pengaruh terhadap nilai penyisihan bahan organik, sehingga dalam menentukan dosis optimum dapat dilihat dari grafik yang awalnya meningkat lalu kemudian mengalami penurunan dan tingkat penyisihan hibrid koagulasi membran UF-SA sebesar 94,050\%.

Dalam mengatasi potensi terjadinya fouling membran, maka pengolahan pada penelitian ini dilengkapi dengan pra-perlakuan koagulasi menggunakan koagulan alami yaitu tanah lempung gambut. Selain dapat menyisihkan bahan organik pada efluen IPAL Pekapuran Raya PD PAL Kota Banjarmasin, penelitian ini juga di fokuskan untuk mengetahui pengaruh pra-perlakuan koagulasi terhadap pembentukan fouling permodelan MFI (Modified Fouling Index), Pore Blocking, dan Kurva Saturasi untuk memprediksi tingkat fouling yang terjadi.

\section{METODE PENELITIAN}

Bahan yang digunakan dalam penelitian ini diantaranya sampel efluen, koagulan TLG, selulosa asetat, dimetil formamide, aseton, akuades, dan Kertas saring dengan pori $0,45 \mu \mathrm{m}$. Peralatan yang digunakan dalam penelitian ini diantaranya plat kaca, labu erlenmeyer $250 \mathrm{~mL}$, gelas beker $500 \mathrm{~mL}, 1000 \mathrm{~mL}$, pengaduk kaca, flokulator FC-4 untuk penentuan dosis optimum, pH meter Hanna, TDS, botol sampel 
$100 \mathrm{~mL}$, pipet Mohr $1 \mathrm{~mL}$ dan $50 \mathrm{~mL}$, bak plastik, gayung, stopwatch, magnetic stirrer, jerigen, sarung tangan, karung, stiker, selotip, kompresor roket, kompresor kros brow, UV-1600 Spectrophotometer, sel UF sistem dead-end, Batang Stainlesstel Elcometer Film Applicator, Scanning Electron Microsscope (SEM), neraca analitik (Sonic Electronic), dan XRF untuk karakterisasi koagulan TLG.

\subsection{Pengambilan dan Karakterisasi Sampel Efluen}

Sampel efluen yang digunakan diambil di Jalan Pasar Pagi No. 89 IPAL Pekapuran Raya PD PAL Kota Banjarmasin. Karakterisasi efluen IPAL dilakukan di Balai Besar Teknik Kesehatan Lingkungan dan Pengendalian Penyakit Banjarbaru meliputi uji (bau, kekeruhan, rasa, suhu, TDS, TSS, pH, Nitrat, Nitrit, $\mathrm{KMnO}_{4}$, COD, BOD, DO, Minyak \& Lemak, dan uji e.coli). Laboratorium Kesehatan Provinsi Kalimantan Selatan (uji DOC). Laboratorium Kimia dan Lingkungan Industri Pertanian Fakultas Pertanian Universitas Lambung Mangkurat (uji $\mathrm{UV}_{254}, \mathrm{UV}_{456}, \mathrm{E}_{4} / \mathrm{E}_{6}$ ). Karakterisasi dilakukan dengan menggunakan dasar Baku Mutu Air Bersih Peraturan Menteri Kesehatan RI No. 32 Tahun 2017 tentang Standar Baku Mutu Kesehatan Lingkungan dan Persyaratan Kesehatan Air untuk keperluan Higiene Sanitasi, Kolam Renang, Solus Per Aqua, dan Pemandian.

\subsection{Pengambilan dan Karakterisasi Koagulan Tanah Lempung Gambut (TLG)}

Sampel TLG yang digunakan diambil di di Kecamatan Gambut yang berjarak $\pm 17 \mathrm{Km}$ dari Kota Banjarmasin Provinsi Kalimantan Selatan. Berdasarkan penelitian Mahmud dkk. (2012), karakterisasi dengan uji XRF diketahui material pembentuk TLG adalah $\mathrm{SiO}_{2}, \mathrm{Al}_{2} \mathrm{O}_{3}, \mathrm{Fe}_{2} \mathrm{O}_{3}, \mathrm{Na}_{2} \mathrm{O}, \mathrm{CaO}, \mathrm{MgO}$, $\mathrm{MnO}, \mathrm{TiO}_{2}, \mathrm{~K}_{2} \mathrm{O}, \mathrm{P}_{2} \mathrm{O}_{5}, \mathrm{SO}_{3}$, LOI, KTK, dan SSA.

\subsection{Pembuatan Membran Ultrafiltrasi Selulosa Asetat (UF-SA)}

Pembuatan larutan membran yaitu dengan komposisi $11 \%$ SA, $30 \%$ dimetil formamida, dan $59 \%$ aseton (Mahmud dkk., 2008; Rahman, 2014). Proses pembuatan membran adalah dengan mencetaknya pada sebidang kaca menggunakan batang stainlesstel elcometer film applicator dengan mengatur ketebalan membran $150 \mu \mathrm{m}$. Membran dibuat dengan teknik inversi fasa, yaitu perubahan dari fasa cair menjadi fasa padat. Karakterisasi membran dilakukan untuk mengetahui jenis membran dengan pengukuran fluks sehingga dapat menentukan permabilitas. Caranya yaitu dengan mengalirkan akuades melalui permukaan membran dan di hitung volume permeat setiap 5 menit selama 1 jam dan di berikan variasi tekanan $1,1.5,2,2.5,3$ bar.

\subsection{Pra-perlakuan Koagulasi}

Percobaan penentuan dosis optimum koagulan dengan cara jar-test $500 \mathrm{~mL}$ menggunakan koagulan TLG variasi dosis $2 \mathrm{~g} / \mathrm{L} ; 3 \mathrm{mg} / \mathrm{L} ; 4 \mathrm{~g} / \mathrm{L} ; 5 \mathrm{~g} / \mathrm{L} ; 6 \mathrm{~g} / \mathrm{L} ; 7 \mathrm{~g} / \mathrm{L}$ melalui proses proses pengadukan cepat 100 rpm selama 1 menit dan dilanjutkan pengadukan lambat selama 40 rpm selama 20 menit. Kemudian melanjutkan dengan proses sedimentasi (diendapkan) selama 10 menit (Khulaifi, 2014). Berikutnya, melakukan penyaringan menggunakan kertas saring dengan pori 0,45 $\mu$ m sebanyak $200 \mathrm{~mL}$. Kemudian melakukan analisis berupa $\mathrm{pH}, \mathrm{UV}_{254}, \mathrm{UV}_{456}$ dan $\mathrm{E}_{4} / \mathrm{E}_{6}$. 


\subsection{Proses Hibrid Koagulasi dan Membran UF-SA}

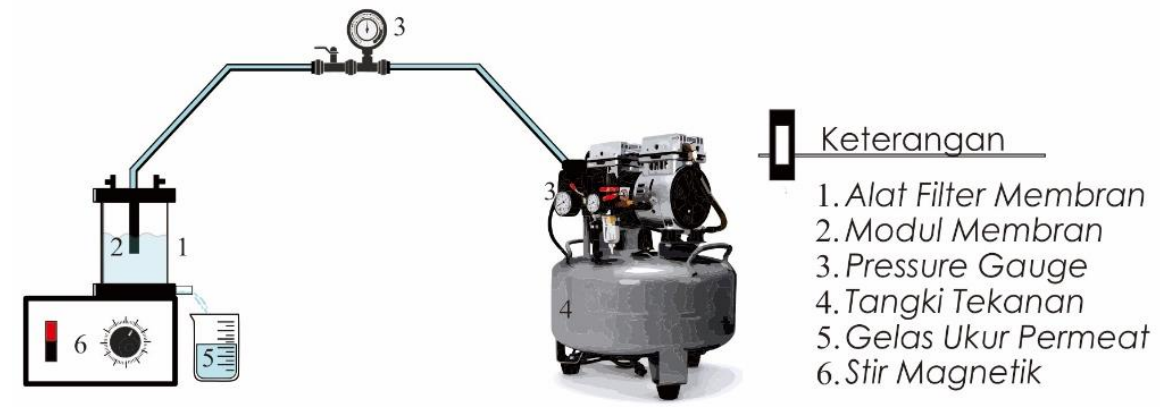

Gambar 2.1 Rangkaian Alat Ultrafiltrasi Aliran Dead-end

Percobaan Proses Hibrid Pra-Perlakuan Koagulasi dan Membran UF-SA dilakukan setelah didapatkan dosis optimum pada proses pra-perlakuan dengan cara meletakkan membran pada kertas saring dengan pori $0,45 \mu \mathrm{m}$ di bawah dan di atas membran serta meletakkan membran ke dalam rangkaian alat ultrafiltrasi sistem dead-end dan memasukkan sampel air efluen yang sudah dilakukan pra-perlakuan sebagai umpan sebanyak $\pm 200 \mathrm{~mL}$ (Herwati dkk., 2015). Mengoperasikan alat filter membran dengan menggunakan dosis koagulasn TLG optimum dengan variasi tekanan sebesar 1, 1.5, 2, 2.5, dan 3 bar dalam waktu 120 menit dan setiap 5 menit diukur volume air yang diolah (volume permeat). Selanjutnya melakukan analisis meliputi uji $\mathrm{pH}, \mathrm{UV}_{254}, \mathrm{UV}_{456}, \mathrm{E}_{4} / \mathrm{E}_{6}$ untuk mengetahui sejauh mana proses koagulasi dapat meningkatkan kinerja dari membran.

\section{HASIL DAN PEMBAHASAN}

\subsection{Karakterisasi Efluen IPAL}

Pengujian karakteristik efluen dilakukan untuk mengetahui perubahan kandungan bahan organik sebelum diolah. Hasil karakterisasi efluen IPAL pada penelitian ini disajikan pada Tabel 3.1. Efluen pada penelitian ini memiliki karateristik $\mathrm{pH}$ yang cenderung netral. Nilai $\mathrm{pH}$ berkisar dari 7,2 - 7,3 dan serupa dengan riset sebelumnya, bahwa pH pada karakteristik air efluen berkisar antara 7,1 - 7,5 (Xue dkk., 2014). Hasil pengujian DOC yaitu sebesar 9,06 mg/L. Hasil tersebut menunjukkan bahwa nilai DOC tergolong tinggi karena mirip dengan hasil Xue dkk. (2014) dengan rentang 9,3 - 11,9 mg/L. Nilai absorbansi $\mathrm{UV}_{254}$ pada penelitian ini berkisar dari 0,185 - 0,193 serupa dengan penelitian Gouttal dkk (2018). Nilai $U_{254}$ dari minggu ke-I sampai minggu ke-IV mengalami perubahan relatif kecil terhadap waktu diduga akibat bahan organik yang mengendap didalam tandon air. Dari nilai $\mathrm{UV}_{254}$ maka dapat dihitung $\mathrm{SUVA}_{254}$ yaitu nilai absorbansi $\mathrm{UV}_{254}$ dikali 100 dibagi dengan nilai DOC. SUVA 254 digunakan untuk mengetahui adanya fraksi hidrofilik dan hidrofobik bahan organik (Matilainen dkk., 2011).

Rata-rata nilai SUVA254 diperoleh sebesar 2,125 L/mg.m. Sesuai dengan penelitian Rosadi (2017) yang memperoleh nilai SUVA 254 sebesar 2,692 L/mg.m. Berdasarkan nilai tersebut, maka efluen IPAL Pekapuran Raya PD PAL Kota Banjarmasin mengandung bahan organik yang berkisar 2 - 4 L/mg.m. dan mengindikasikan bahwa komposisi bahan organik dalam efluen terdiri dari campuran hidrofobik dan hidrofilik dengan BM campuran besar dan kecil (Edzwald dan Tobiason, 1999; Mahmud dkk., 2012). Hal ini diduga karena kontaminasi efluen yang tercampur oleh bahan - bahan kimia (sabun) sehingga dihasilkan adanya campuran hidrofobik yang tinggi. Nilai zat organik $\mathrm{KMnO}_{4}$ adalah 19,9 mg/L $\mathrm{KMnO}_{4}$ diuji di laboratorium BBTLKPP dengan menggunakan SNI 06-6989.222004. Hasil tersebut diketahui masih melebihi kadar maksimum berdasarkan Peraturan Menteri 
Kesehatan RI No. 32 Tahun 2017 tentang Standar Baku Mutu Kesehatan Lingkungan dan Persyaratan Kesehatan Air untuk keperluan Higiene Sanitasi, Kolam Renang, Solus Per Aqua, dan Pemandian. yaitu $10 \mathrm{mg} / \mathrm{L} \mathrm{KMnO}_{4}$.

Tabel 3.1 Hasil Uji Karakteristik Awal Efluen IPAL Selama 4 Minggu

\begin{tabular}{|c|c|c|c|c|c|c|c|c|}
\hline \multirow{2}{*}{ No } & \multirow{2}{*}{ Parameter } & \multirow{2}{*}{ Satuan } & \multicolumn{4}{|c|}{ Minggu ke- } & \multirow{2}{*}{ Rata-rata } & \multirow{2}{*}{$\begin{array}{l}\text { Standar } \\
\text { Deviasi }\end{array}$} \\
\hline & & & I & II & III & IV & & \\
\hline 1 & $\mathrm{pH}$ & - & 7,2 & 7,2 & 7,3 & 7,3 & 7,25 & 0.058 \\
\hline 2 & DOC & $\mathrm{mg} / \mathrm{L}$ & \multicolumn{4}{|c|}{9,059} & 9,06 & \\
\hline 3 & $\mathrm{UV}_{254}$ & $1 / \mathrm{cm}$ & 0,185 & 0,195 & 0,197 & 0,193 & 0,193 & 0.005 \\
\hline 4 & SUVA & L/mg.m & 2,042 & 2,153 & 2,175 & 2,130 & 2,125 & 0.058 \\
\hline 5 & $\mathrm{KMnO}_{4}$ & $\mathrm{mg} / \mathrm{L} \mathrm{KMnO}_{4}$ & \multicolumn{4}{|c|}{19,9} & 19,9 & \\
\hline
\end{tabular}

\subsection{Karakterisasi Koagulan TLG}

TLG yang berasal dari Kecamatan Gambut Km 17, Kabupaten Banjar memiliki ciri-ciri berwarna cokelat tua kehitaman, lunak seperti lempung, dan tidak mudah rapuh. Koagulan TLG pada penelitian ini disajikan pada Gambar 3.1.

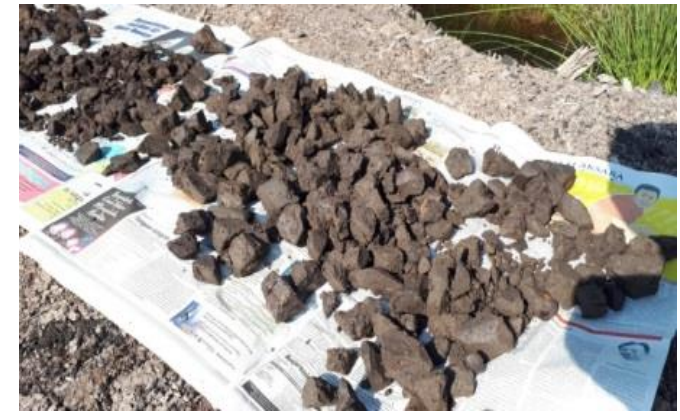

Gambar 3.1 Koagulan TLG dari Kecamatan Gambut Km 17, Kabupaten Banjar

TLG ini memiliki kandungan bahan organik yang relatif besar karena TLG tersebut berada dibawah lapisan gambut yang kaya dengan bahan organik. Karakterisasi yang dilakukan yaitu melakukan pengujian $\mathrm{pH}$ dari TLG dengan mesh 10/40, didapatkan hasil pH=3,18. Hasil tersebut sesuai dengan penelitian Khulaifi (2016). Kandungan yang didominasi oleh mineral yang bisa menjadikan TLG sebagai koagulan seperti $\mathrm{Al}_{2} \mathrm{O}_{3}$ dan $\mathrm{Fe}_{2} \mathrm{O}_{3}$. Oksida utama yang ditemukan dalam TLG adalah berupa silica, alumina dan oksidasi besi.

\subsection{Karakterisasi Membran UF-SA}

\section{Permeabilitas}

Pada Gambar 3.2 dapat dilihat bahwa semakin tinggi tekanan operasi yang diberikan yaitu tekanan 1 3 bar maka fluks yang dihasilkan juga semakin tinggi. Nilai fluks tertinggi didapatkan pada tekanan 3 bar yaitu 223,8 L/jam.m². Sedangkan fluks terendah terdapat pada tekanan 1 bar yaitu 41,4 L/jam. ${ }^{2}$. Permeabilitas merupakan gradien kemiringan kurva dari nilai fluks (J) terhadap tekanan (P). Dari grafik tersebut nilai fluks yang diperoleh pada tiap variasi tekanan operasi di didapatkan nilai permeabilitas sebesar $87,3 \mathrm{~L} / \mathrm{m}^{2}$.jam.bar. Menurut literatur permeabilitas membran UF berada pada 
kisaran 20 - $200 \mathrm{~L} / \mathrm{m}^{2}$.jam.bar (Herwati dkk., 2015). Berdasarkan nilai permeabilitas, maka membran selulosa asetat yang dibuat dapat dikategorikan sebagai membran UF.

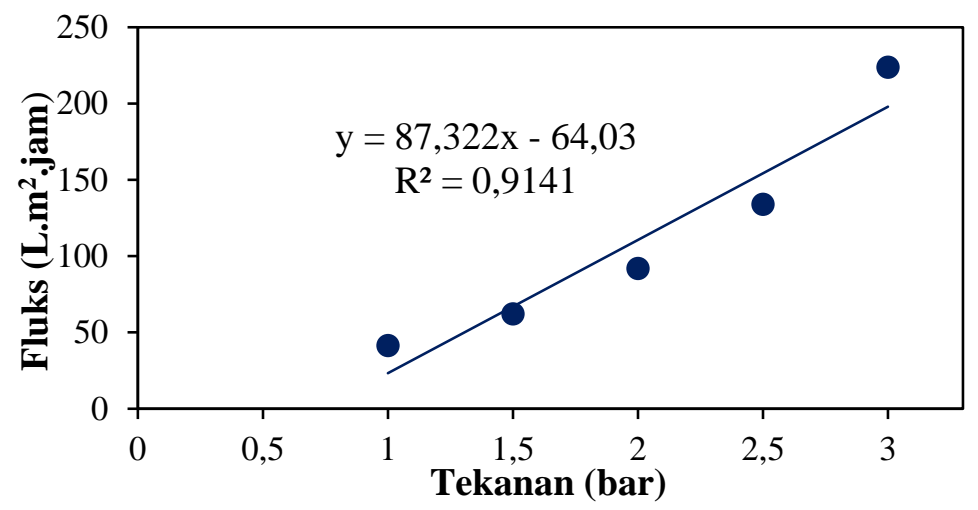

Gambar 3.2 Nilai Fluks Akuades Terhadap Perubahan Tekanan Operasi

\section{Analisis Morfologi Membran}

SEM (Scanning Microscope Electron) digunakan untuk menganalisis morfologi membran selulosa asetat. Membran diuji menggunakan perbesaran 1500x dan 1800x dengan foto permukaan dan tampang melintang. Gambar foto SEM disajikan sebagai berikut:
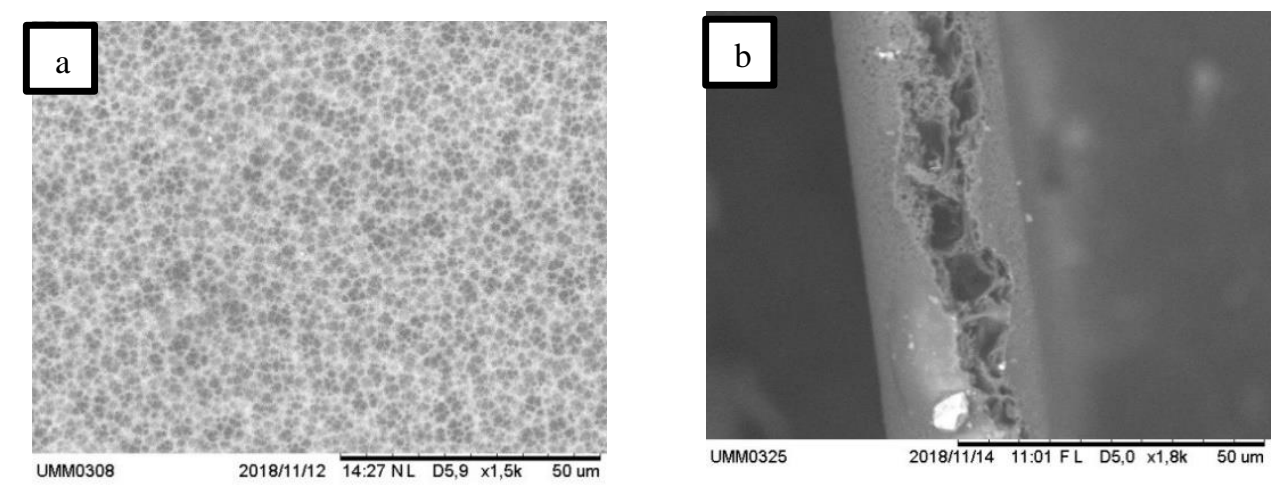

Gambar 3.3 Foto SEM Membran Selulosa Asetat sebelum digunakan (a) tampak permukaan dan (b) penampang melintang

Hasil dari foto SEM membran selulosa asetat sebelum digunakan terlihat pada gambar permukaan membran seperti bukan pori membran, diduga karena pada proses SEM tidak diberi coating atau diduga terbakar karena membran pada saat pelapisan sebelumnya tidak sempurna. Pada bagian tampang melintang ketebalan membran berkisar $50 \mu \mathrm{m}$, jika ditotalkan ketebalan smembran ini adalah sebesar $150 \mu \mathrm{m}$. Menurut Wardani (2013) membran ultrafiltrasi memiliki kategori dengan ketebalan $150 \mu \mathrm{m}$. 

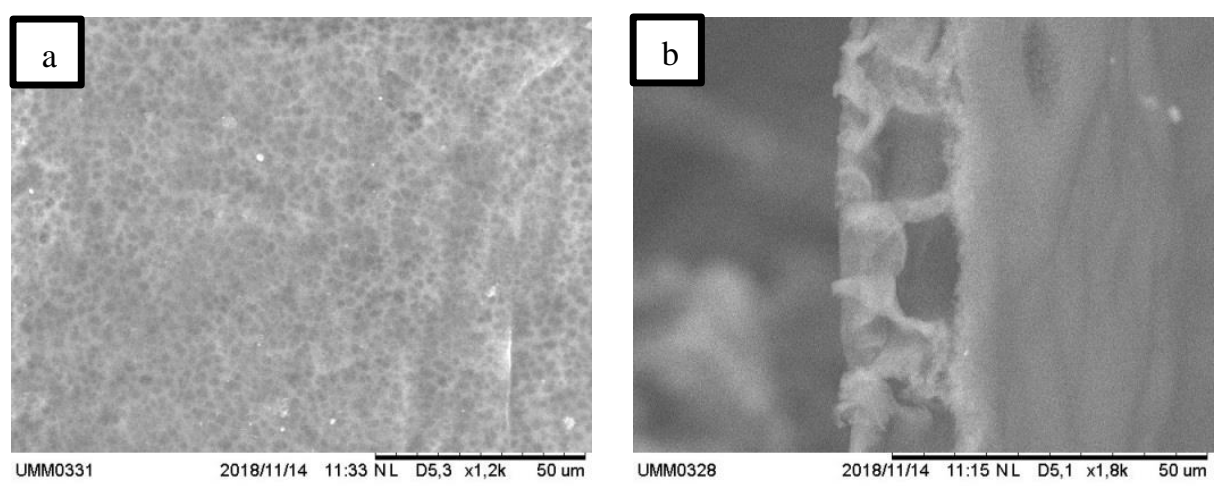

Gambar 3.4 Foto SEM Membran Selulosa Asetat Setelah digunakan (a) tampak permukaan dan (b) penampang melintang

Gambar 3.4 menampilkan foto SEM membran selulosa asetat setelah digunakan untuk filtrasi air efluen selama 120 menit pada proses hibrid koagulasi dan membran, dapat dilihat tampak pada permukaan membran kurang halus dikarenakan pada saat mencetak kurang ketelitian sehingga terdapat pori yang besar. Sedangkan SEM tampang melintang hanya sedikit pori yang dapat terlihat, hal tersebut diduga karena kesalahan yang terjadi pada saat preparasi sampel membran.

\subsection{Proses Hibrid Koagulasi dan Membran UF-SA \\ 3.4.1 Proses Pra-perlakuan Koagulasi}

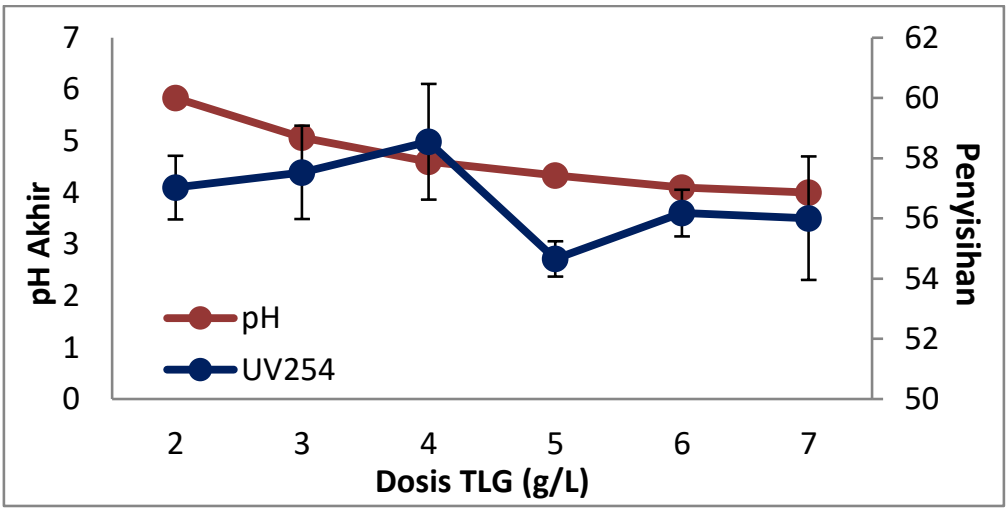

Gambar 3.5 Pengaruh Dosis TLG Terhadap Penyisihan UV 254 Serta Nilai pH Akhir Untuk Kondisi pH Awal 6 dan $\mathrm{UV}_{254}$ awal 0,197 1/cm.

Dari gambar 3.5 diketahui bahwa dosis optimum koagulan TLG adalah $4 \mathrm{~g} / \mathrm{L}$. Dosis koagulan dianggap optimum karena mempunyai nilai penyisihan $\mathrm{UV}_{254}$ dengan penurunan paling besar yaitu 58,54 \% sehingga dapat dikatakan bahwa kualitas penyisihan terbaik. Sesuai dengan penelitian Rahman (2014) yang menyatakan bahwa dalam menentukan dosis optimum koagulan dapat dilihat dititik dimana dosis mengalami penurunan atau proses restabilisasi. Dengan nilai awal pH 6 menjadi 4,2. Penurunan $\mathrm{pH}$ ini disebabkan karena sifat TLG yang asam.

Hasil Penyisihan $\mathrm{UV}_{456}$ disajikan pada Gambar 3.6. Hasil ini untuk mengidentifikasi kandungan warna dari sampel efluen. 


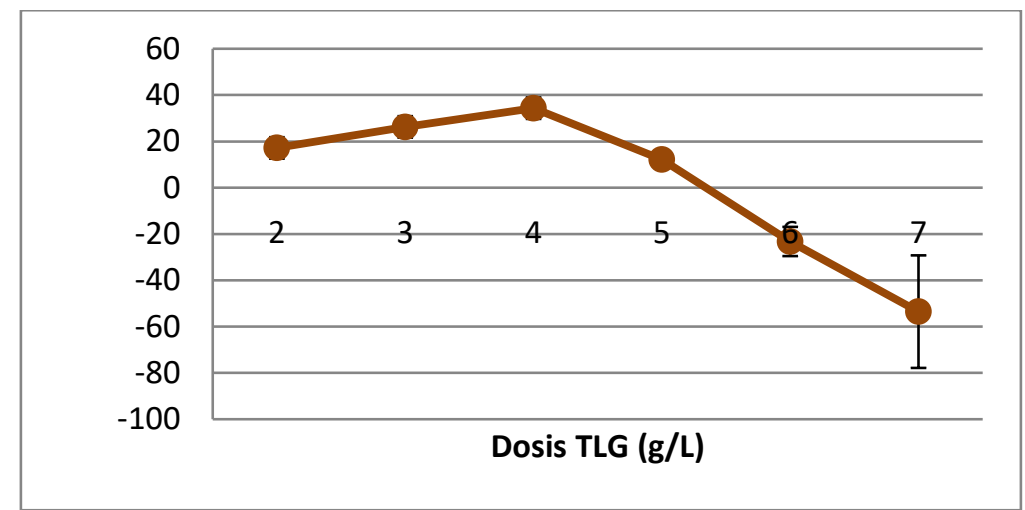

Gambar 3.6 Pengaruh Dosis TLG Terhadap Penyisihan $U V_{456}$ dengan Nilai $\mathrm{UV}_{456}$ awal $0,0331 / \mathrm{cm}$.

Pada dosis $4 \mathrm{~g} / \mathrm{L}$ Nilai $\mathrm{UV}_{456}$ penyisihannya cukup tinggi yaitu 34,3\% dengan rata-rata nilai UV 456 yaitu 0,021. Apabila angka yang dihasilkan semakin tinggi maka warna nya akan pekat. Hal ini disebabkan oleh pengaruh kandungan organik yang tinggi. Sedangkan pada dosis $7 \mathrm{~g} / \mathrm{L}$ Nilai $\mathrm{UV}_{456}$ penyisihannya rendah yaitu $-53,5 \%$ dengan rata-rata nilai $\mathrm{UV}_{456}$ yaitu 0,059 . Hal ini diduga karena pengaruh kelebihan dosis TLG.

Hasil Penyisihan $\mathrm{E}_{4} / \mathrm{E}_{6}$ disajikan pada Gambar 3.7. Hasil ini untuk mengidentifikasi ukuran molekul dari sampel efluen dengan rasio $\mathrm{UV}_{465}$ dan $\mathrm{UV}_{656 .}$

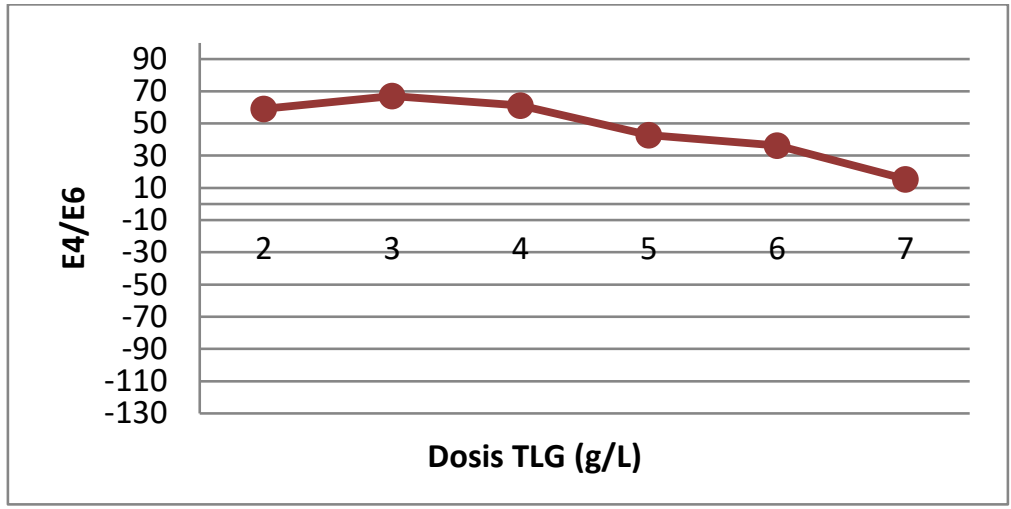

Gambar 3.7 Pengaruh Dosis TLG Terhadap Penyisihan $\mathrm{E}_{4} / \mathrm{E}_{6}$ dengan Nilai $\mathrm{E}_{4} / \mathrm{E}_{6}$ awal $3,51 / \mathrm{cm}$.

Berdasarkan Gambar 3.7 menunjukkan nilai yang naik turun pada setiap variasi dosis yang diberikan. Nilai $\mathrm{E}_{4} / \mathrm{E}_{6}$ berkisar 1,15 - 2,90, yang menunjukkan bahwa apabila nilanya besar, maka didalam air tersebut banyak terdapat molekul-molekul dengan ukuran kecil, namun apabila angka yang terbaca kecil, maka didalam air tersebut terdapat molekul-molekul dengan ukuran relatif besar. Hasil tersebut berbeda dengan Putra (2014) yang nilai $\mathrm{E}_{4} / \mathrm{E}_{6}$ berkisar $0,85-1,851 / \mathrm{cm}$. Hal ini disebabkan karena jenis dan dosis koagulan yang diberikan berbeda. 


\subsubsection{Hibrid Koagulasi dan Membran UF-SA}

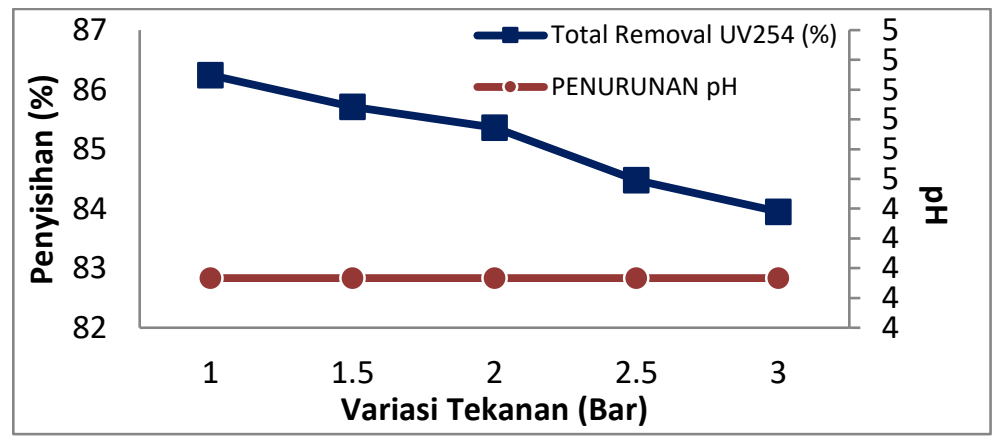

Gambar 3.8 Pengaruh Variasi Tekanan dengan Dosis TLG 4 g/L Terhadap

Penyisihan $\mathrm{UV}_{254}$ Serta Nilai $\mathrm{pH}$ Akhir Untuk Kondisi pH awal 6 dan Nilai $\mathrm{UV}_{254}$ awal $0,1891 / \mathrm{cm}$.

Pada Gambar 3.8 tingkat penyisihan $\mathrm{UV}_{254}$ efluen semakin menurun seiring dengan peningkatan tekanan operasi yang diberikan pada membran. Hal tersebut diakibatkan oleh melebarnya pori membran yang menyebabkan kontaminan bahan organik akan melewati kedalam aliran permeat membran. Hasil yang diperoleh tersebut sesuai dengan riset sebelumnya yang menyatakan bahwa besarnya rejeksi bahan organik berbanding terbalik dengan tekanan (Notodarmojo dan Deniva, 2004). Tingkat penyisihan parameter $\mathrm{UV}_{254}$ sebesar 83,9\%-86,2\%. Penelitian ini menunjukkan proses hibrid dapat meningkatkan penyisihan $\mathrm{UV}_{254}$ dari sebelumnya pada koagulasi hanya sebesar 58,5\%. Dengan dilakukan pra-perlakuan koagulan maka, bahan organik dengan berat molekul rendah akan membentuk flok-flok dengan diameter yang lebih besar, sehingga dapat ditahan oleh membran dan tidak masuk ke dalam pori-pori membran (Mahmud dan Noor, 2005).

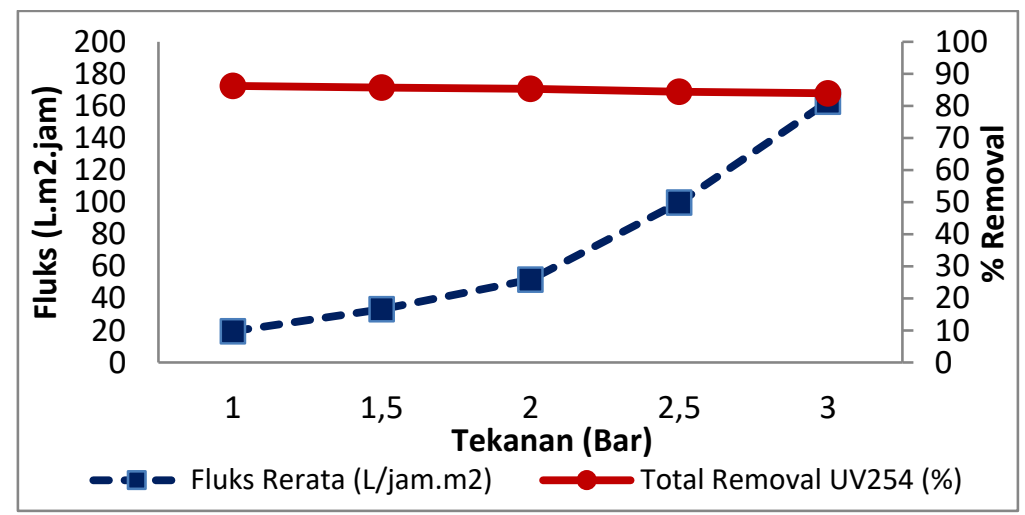

Gambar 3.9 Pengaruh Variasi Tekanan dengan Dosis TLG 4 g/L Terhadap

Nilai Fluks dan Tingkat Penyisihan Bahan Organik Pada Proses Hibrid Koagulasi dan Membran UF-SA

Hal yang diinginkan dalam proses membran yaitu meningkatkan kinerja fluks dan selektivitas, sehingga dapat dipilih tekanan terbaik. Berdasarkan Gambar 3.9 tekanan optimum yaitu tekanan 3 bar karena pertimbangan pada tekanan tersebut memiliki fluks yang paling tinggi yaitu $162,645 \mathrm{~L} / \mathrm{jam} . \mathrm{m}^{2}$ 
dan tingkat penyisihannya sebesar $83,95 \%$. Serta bertemunya titik di tekanan 3 bar antara penyisihan dan nilai fluks.

Pada proses hibrid, nilai $\mathrm{UV}_{456}$ dilakukan dengan dosis TLG 4 g/L terhadap variasi tekanan, pada tekanan 1 bar tingkat penyisihan warna yaitu $67,7 \%$ rata-rata nilai $\mathrm{UV}_{456}$ yaitu 0,009 . Sedangkan pada tekanan 3 bar tingkat penyisihannya sebesar $61,1 \%$ dengan rata-rata nilai $U V_{456}$ yaitu 0,011. Diketahui pada proses hibrid perubahan warna oleh nilai $\mathrm{UV}_{456}$ semakin menurun sehingga warna yang dihasilkan lebih jernih. Dan pada proses hibrid nilai $\mathrm{E}_{4} / \mathrm{E}_{6}$ berkisar 1,56 - 2,18 dengan penyisihannya berkisar 41,7 \% - 58,5\%. Hal ini menunjukkan setelah proses hibrid ukuran molekul yang disisihkan adalah yang relatif kecil yang artinya adalah molekul - molekul yang berukuran besar lebih mendominasi.

\subsubsection{Proses Hibrid Koagulasi dan Membran UF-SA Dengan Tekanan Optimum Untuk Dosis Optimum}

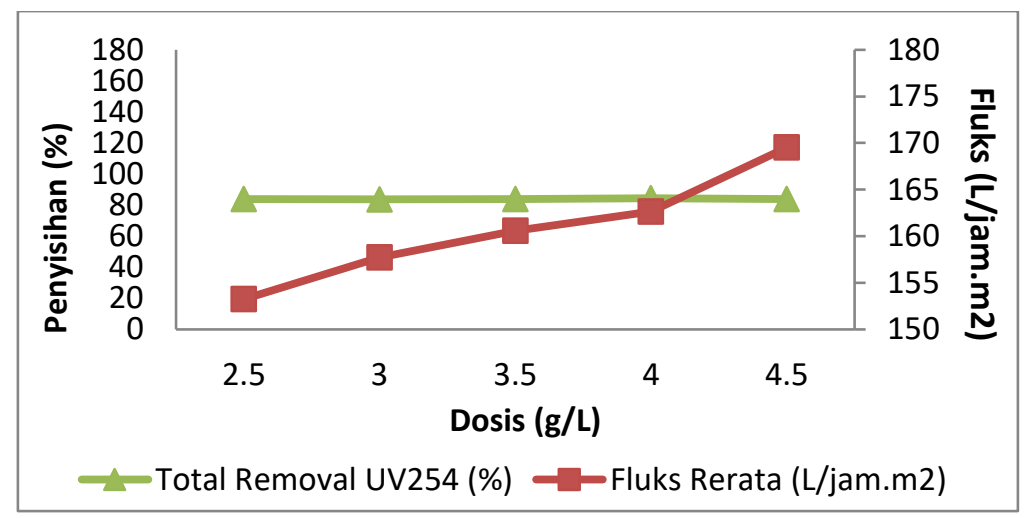

Gambar 3.10 Pengaruh Variasi Dosis Terhadap Nilai Fluks dan Tingkat Penyisihan $\mathrm{UV}_{254}$ dengan Tekanan Optimum 3 Bar Proses Hibrid Koagulasi dan Membran UF-SA

Berdasarkan Gambar 3.10 pengaruh variasi dosis TLG dari 2,5 g/L - 4,5 g/L dengan tekanan optimum 3 bar adalah fluks nya meningkat pada setiap penambahan dosis, dan penyisihannya menurun. Fluks dosis dengan rata - rata 153,2 - 169,5 L/jam.m ${ }^{2}$ dengan penyisihan 83,9\% - 84,4 \%. Berdasrkan hasil yang dilakukan dosis optimum TLG didapatkan tetap pada dosis $4 \mathrm{~g} / \mathrm{L}$.

\subsection{Permodelan Fouling Proses Hibrid}

Salah satu permodelan fouling yaitu MFI, dilihat dari hasil nilai MFI nya yang menunjukan bahwa tekanan 1 bar memiliki potensi fouling yang besar sedangkan potensi fouling paling kecil terdapat pada tekanan 3 bar. Kurva tersebut menggambarkan fluks yang dihasilkan pada tekanan 1 bar terlihat paling kecil dibandingkan tekanan yang lainnya berarti bahwa pada tekanan tersebut akan terjadi potensi fouling yang lebih besar dibandingkan tekanan lainnya. 


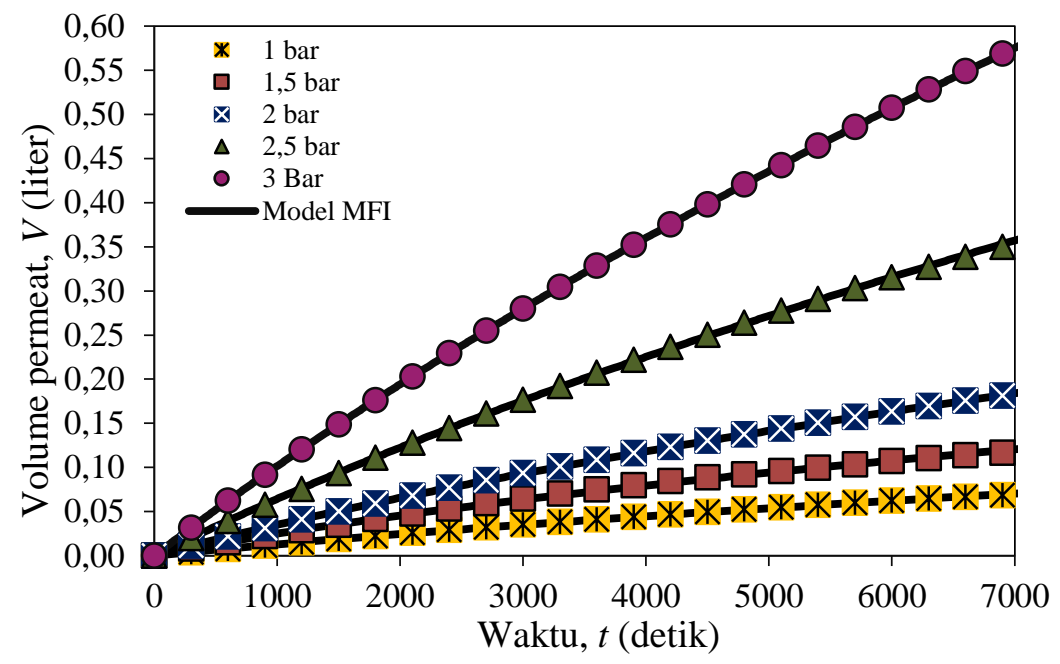

Gambar 3.11 Permodelan MFI pada Masing-Masing Tekanan

Selain MFI, salah satu permodelan yang dapat dipakai guna memodelkan tingkat fouling adalah pore blocking.

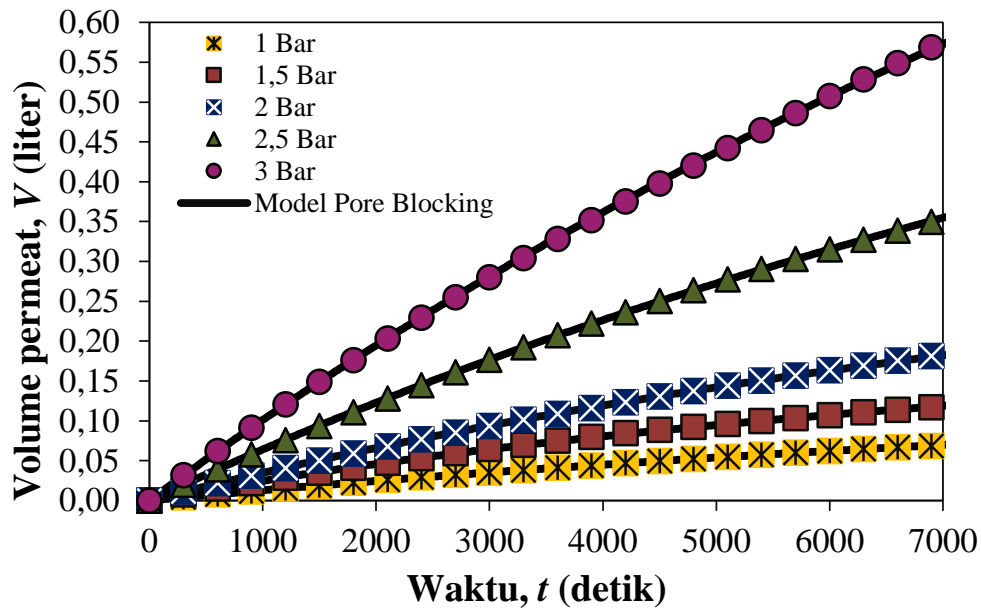

Gambar 3.12 Permodelan Pore Blocking pada Masing-Masing Tekanan

Pada Gambar 3.12 gradient pore blocking terbesar berada pada tekanan 1 bar dan terkecil berada pada telanan 3 bar. Hal ini menunjukkan bahwa pada tekanan 1 bar penyumbatan pori yang terjadi lebih sedikit. Besarnya gradient pore blocking mengakibatkan semakin cepatnya terjadi penyumbatan pada pori membran (Herwati dkk., 2015).

Kemudian salah satu peristiwa fouling yang juga dapat terjadi adalah proses kejenuhan. Tingkat kejenuhan membran dapat dimodelkan dengan model kurva saturasi. Semakin besar nilai Vmax maka semakin rendah tingkat kejenuhan yang terjadi pada membran. Tabel 4.4 terlihat bahwa nilai Vmax terbesar berada pada tekanan 3 bar. Hal ini menunjukkan bahwa model kurva saturasi konsisten sehingga dapat mempresentasikan tingkat jenuh pada masing-masing tekanan. Oleh karena itu, potensi 
fouling pada permodelan yang lebih tepat karena mendekati fouling adalah permodelan Kurva Saturasi dengan $R^{2}=1$. Kurva Saturas disajikan pada Gambar 3.13.

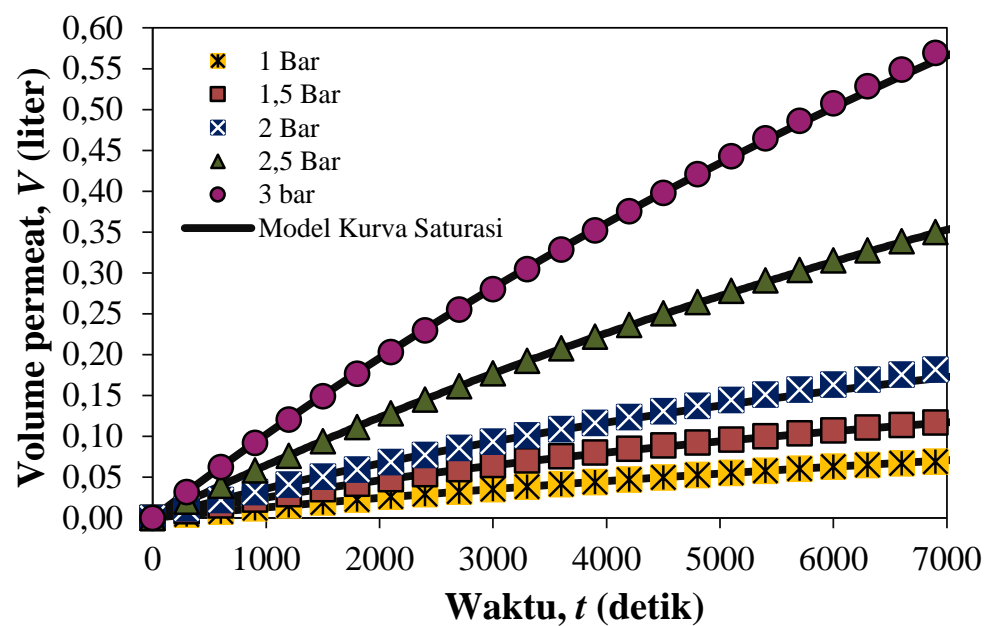

Gambar 3.13 Permodelan Kurva Saturasi pada Masing-Masing Tekanan

\section{KESIMPULAN}

Kesimpulan yang dapat diambil dari penelitian ini adalah :

1. Kondisi operasi terbaik proses hibrid koagulasi dan membran UF-SA yaitu pada tekanan operasi 3 bar menggunakan dosis optimum TLG 4 g/L, mampu menyisihan UV 254 sebesar 83,9 $\%$ serta menghasilkan fluks sebesar 162,645 L/jam.m².

2. Permodelan fouling membran yang paling tepat dalam menggambarkan proses hibrid koagulasi dan membran UF-SA adalah Kurva Saturasi dengan R square tekanan 3 bar yaitu 1.

\section{DAFTAR PUSTAKA}

Aprilia, S dan A. Amin. 2011. Sintesis dan Karakterisasi Membran untuk Proses Ultrafiltrasi. Rekayasa Kimia dan Lingkungan, 8(2): 84-88.

Aryanti, P. T. P., Khoiruddin dan I. G. Wenten. 2013. Influence of Additives on Polysulfone-Based Ultrafiltration Membrane Performance during Peat Water Filtration. Journal of Water Sustainability. 3(2): 85-96.

Dong, B., C. Yan., G. N. Yun and F. J. Chu. 2007. Effect of Coagulan Pretreatment on the Fouling of Ultrafiltration Membrane. Journal of Environmental Sciences, 19: 278-283.

Edzwald, J. K. dan J. E. Tobiason. 1999. Enchanced Coagulation: US Requirements and a Broader View. Water Science and Technology, 40(9), 63-70.

Fitria, D. L. Handayani. 2010. Studi Two Stage Coagulation Untuk Menurunkan Kandungan Organik Pada Air Baku Air Minum Kota Padang. TeknikA, 33(1): 94-106.

Gouttal, K. A. Benghalem, G, Mimanne. 2018. Removal of Organic Matter From Wastewater Using M/Al-pillared Clays ( $\mathrm{M}=\mathrm{Fe}$ or $\mathrm{Mn})$ as Coagulants. Water Science \& Technology, 78(3):534544.

Herwati, N., Mahmud dan C. Abdi. 2015. Pengaruh pH Air Gambut Terhadap Fouling Membran Ultrafiltrasi. Jukung Jurnal Teknik Lingkungan. 1(1):59-73. 
Khulaifi, M. N. 2016. Skala Pilot Produksi Air Bersih Dari Air Gambut Menggunakan Proses Gabungan Koagulasi Dengan Tanah Lempung Gambut (TLG) Dan Adsorpsi Karbon Aktif. Tugas Akhir. Program Studi Teknik Lingkungan. Universitas Lambung Mangkurat. Banjarbaru.

Mahmud dan R. Noor. 2005. Kinetika Fouling Membran Ultrafiltrasi (UF) Pada Pengolahan Air Berwarna: Pengaruh Interval dan Lamanya Pencucian Balik (Backwashing) Membran. InfoTeknik. 6(1) : 62-69.

Mahmud., M. Badaruddin dan S. Notodarmojo. 2008. Pengolahan Air Gambut Menggunakan Proses Hibrid Adsorpsi-Crossflow Ultafiltrasi Dengan Tanah lempung gambut (TLG) Sebagai Adsorben. Jurnal Teknik Lingkungan. 14.

Mahmud., S. Notodarmojo., T. Padmi dan P. Soewondo. 2012. Adsorpsi Bahan Organik Alami (BOA) Air Gambut Pada Tanah Lempung Gambut Alami dan Teraktivasi:Studi Kesetimbangan Isoterm dan Kinetika Adsorpsi. Info Teknik, 13(1):28-38.

Matilainen, A., E. T. Gjessing, T. Lahtinen, L. Hed, A. Bhatnagar dan M. Silanpaa. 2011. An Overview of the Methods Used in the Characterisation of Natural Organic Matter (NOM) in Relation to Drinking Water Treatment. Chemosphere. 83 2011. 1431-1442.

Notodarmojo, S dan A. Deniva. 2004. Penurunan Zat Organik dan Kekeruhan Menggunakan Teknologi Membran Ultrafiltrasi dengan Sistem Aliran Dead-End (Studi Kasus : Waduk Saguling, Padalarang). PROC. ITB Sains \& Tek, 36A(1): 63-82.

Pratiwi, A. E. 2017. Pengaruh Pra-Perlakuan Koagulasi Adsorpsi Terhadap Fouling Membran Ultrafiltrasi Polisulfon (UF-Psf) Pada Penyisihan Bahan Organik Alami (BOA) Air Gambut. Tugas Akhir. Program Studi Teknik Lingkungan. Universitas Lambung Mangkurat. Banjarbaru.

Putra, Y. T. 2014. Pengolahan Air Sungai Skala Pilot Dengan Menggunakan Proses Hibrid: Koagulasi dan Membran Ultrafiltrasi. Tugas Akhir. Program Studi Teknik Lingkungan. Universitas Lambung Mangkurat. Banjarbaru.

Rachma, E. R., J. A. Pinem dan I. Amri. 2018. Pembuatan Membran Ultrafiltrasi Selulosa Asetat Untuk Pengolahan Limbah Cair Mal. Jom FTEKNIK, 5(1):1-3.

Rahman, R. A. 2014. Proses Hibrid Koagulasi-Ultrafiltrasi Pada Penyisihan Bahan Organik Alami (BOA) Dalam Air Gambut: Pengaruh Jenis Koagulan dan Kecepatan Pengadukan terhadap Fouling Membran. Tugas Akhir. Program Studi Teknik Lingkungan. Universitas Lambung Mangkurat. Banjarbaru.

Rosadi, R. Mahmud., dan C. Abdi. 2017. Pengaruh Proses Hibrid Koagulasi Dua Tahap dan Membran Ultrafiltrasi Polisulfon Terhadap Penyisihan Bahan Organik Alami Air Gambut. Jukung Jurnal Teknik Lingkungan, 3(2):55-69.

Rusydi, A. F., D. Suherman dan N. Sumawijaya. 2016. Pengolahan Air Limbah Tekstil Melalui Proses Koagulasi-Flokulasi dengan Menggunakan Lempung Sebagai Penyumbang Partikel Tersuspensi Studi Kasus: Banaran, Sukoharjo dan Lawean, Kerto Suro, Jawa Tengah. Arena Tekstil, 31(2):105-114.

Sillanpää, M. 2015. Natural Organic Matter in Water. Butterworth-Heinemann.

Wardani, A. K. 2013. Pengaruh Aditif pada Pembuatan Membran Ultrafiltrasi Berbasis Polisulfon untuk Pemurnian Air Gambut.

Xue, S., Q. Zhao., L. Wei., X. Ma., Y. Wen., dan Z. Zhang. 2014. Reduction of Dissolved Organic Matter in Secondary Municipal Effluents by Enchanced Coagulation. Environmental Progress \& Sustainable Energy, 00(00), 1-10. 
JTAM Teknik Lingkungan Universitas Lambung Mangkurat, Vol 2 (1) Tahun 2019

Halaman ini sengaja dikosongkan 